\title{
Role of ATRX in chromatin structure and function: implications for chromosome instability and human disease
}

\author{
Rabindranath De La Fuente, Claudia Baumann and Maria M Viveiros \\ Department of Physiology and Pharmacology, College of Veterinary Medicine, University of Georgia, \\ 501 D.W. Brooks Drive, Athens, Georgia 30602, USA \\ Correspondence should be addressed to R De La Fuente; Email: rfuente@uga.edu
}

\begin{abstract}
Functional differentiation of chromatin structure is essential for the control of gene expression, nuclear architecture, and chromosome stability. Compelling evidence indicates that alterations in chromatin remodeling proteins play an important role in the pathogenesis of human disease. Among these, $\alpha$-thalassemia mental retardation X-linked protein (ATRX) has recently emerged as a critical factor involved in heterochromatin formation at mammalian centromeres and telomeres as well as facultative heterochromatin on the murine inactive $X$ chromosome. Mutations in human ATRX result in an X-linked neurodevelopmental condition with various degrees of gonadal dysgenesis (ATRX syndrome). Patients with ATRX syndrome may exhibit skewed X chromosome inactivation (XCI) patterns, and ATRX-deficient mice exhibit abnormal imprinted $\mathrm{XCI}$ in the trophoblast cell line. Non-random or skewed $\mathrm{XCI}$ can potentially affect both the onset and severity of $X$-linked disease. Notably, failure to establish epigenetic modifications associated with the inactive $X$ chromosome (Xi) results in several conditions that exhibit genomic and chromosome instability such as fragile $X$ syndrome as well as cancer development. Insight into the molecular mechanisms of ATRX function and its interacting partners in different tissues will no doubt contribute to our understanding of the pathogenesis of ATRX syndrome as well as the epigenetic origins of aneuploidy. In turn, this knowledge will be essential for the identification of novel drug targets and diagnostic tools for cancer progression as well as the therapeutic management of global epigenetic changes commonly associated with malignant neoplastic transformation.

Reproduction (2011) 142 221-234
\end{abstract}

Emerging roles of $\alpha$-thalassemia mental retardation $X$-linked protein in chromatin remodeling and control of gene expression

The $\alpha$-thalassemia mental retardation $X$-linked protein (ATRX) is a member of the Switch 2, sucrose nonfermenting 2 (SWI2/SNF2) family of helicases/ATPases that exhibits chromatin remodeling activity (Picketts et al. 1996, Gibbons et al. 1997, Villard et al. 1997, Xue et al. 2003, Tang et al. 2004a). The ATRX gene maps to the long arm of the human $X$ chromosome and is subject to X chromosome inactivation (XCl; Gibbons et al. 1995, 2008). It encodes a $280 \mathrm{kDa}$ protein with an unusual $\mathrm{N}$-terminal plant homeodomain (PHD) flanked by a coil-coil motif termed the ATRX-DNMT3-DNMT3L (ADD) domain due to its similarity to a protein region found in this group of DNA methyl transferases. The protein also contains several helicase domains at the carboxyl terminal region conferring ATPase activity and essential for interaction with several factors including the human methyl $\mathrm{CpG}$ binding protein MeCP2 (Picketts et al. 1998, Bérubé et al. 2000, Argentaro et al. 2007, Nan et al. 2007). ATRX also encodes a truncated isoform of $\sim 200 \mathrm{kDa}$ lacking the helicase domain (Garrick et al.
2004). Comparison of the nucleotide sequence revealed that the human and mouse genes exhibit $85 \%$ sequence identity and, therefore, a high level of evolutionary conservation (Picketts et al. 1998). In addition to the helicase domains, the protein contains a stretch of glutamic acid residues and a coil-coil domain. Hence, it has the potential to establish a direct interaction with DNA as well as with several functional partners, presumably assembling with different chromatin remodeling or transcriptional regulatory complexes according to the cell type, stage of the cell cycle, or stage of differentiation (Ishov et al. 2004, Tang et al. 2004a, Argentaro et al. 2007, Nan et al. 2007, Kernohan et al. 2010).

Spontaneous mutations in the human ATRX gene induce a complex neurological syndrome that includes mild $\alpha$-thalassemia, mental retardation with facial anomalies, and in extreme cases gonadal dysgenesis (ATRX syndrome; Gibbons et al. 1995, 2003). Somatic mutations in ATRX were initially associated with a hematological phenotype consistently detected in patients with ATRX syndrome, exhibiting a mild form of $\alpha$-thalassemia that is characterized by a reduction in a-globin gene expression and the accumulation of abnormal hemoglobin, detectable as intracellular 
inclusions in peripheral blood cells (Gibbons et al. 2003). Therefore, ATRX was initially described as a critical transcriptional regulator of globin gene expression. However, the diverse clinical manifestations of ATRX syndrome remained unexplained (Gibbons et al. 1995, 2003). Since then, more than 120 mutations have been reported in human ATRX (Picketts et al. 1996, Gibbons et al. 2008). Interestingly, most female carriers are unaffected due to preferential inactivation of the $X$ chromosome that harbors the mutation. These patterns of 'skewed' $\mathrm{XCl}$ are commonly observed in patients with $X$-linked mental retardation (XLMR) and other X-linked conditions (Migeon 2006, Raymond 2006, Muers et al. 2007). Thus, like most cases of XLMR, ATRX syndrome is predominantly observed in males (Gibbons \& Higgs 2000, Raymond 2006).

Analysis of mice heterozygous for a null Atrx allele revealed that this pattern of skewed $\mathrm{XCl}$ is mainly due to a positive, tissue-specific, selection of cells expressing normal levels of ATRX (Muers et al. 2007). However, non-random $\mathrm{XCl}$ has recently been described in a 4-yearold girl with a totally skewed XCl pattern in which the $\mathrm{X}$ chromosome carrying a common ATRX mutation (R246C) remained active (Badens et al. 2006). Interestingly, she was conceived following IVF and showed abnormal methylation patterns at the FMR1 loci (Badens et al. 2006). Expansions in FMR1 are associated with mental retardation in cases of fragile $X$ syndrome (Raymond 2006). Whether skewed XCl in this patient was due to some form of cell selection or whether the mutation affected the process of $\mathrm{XCl}$ remains to be determined.

\section{ATRX: in sickness and in health}

Various studies have shown that ATRX is present at pericentric heterochromatin domains in human and mouse somatic cells and is involved in regulating DNA methylation at ribosomal DNA as well as subtelomeric repetitive sequences of the human genome (Gibbons et al. 1997, 2000, Picketts et al. 1998, McDowell et al. 1999). Notably, ATRX has recently emerged as a major epigenetic regulator of chromatin structure and function during mitosis as well as meiosis (De La Fuente et al. 2004, Ritchie et al. 2008, Baumann et al. 2010) with important clinical implications for chromosome stability during development as well as malignant neoplastic transformation (Bérubé et al. 2002, 2005, Banaszynski et al. 2010, Kernohan et al. 2010, Elsasser et al. 2011, Jiao et al. 2011). For example, seminal studies have recently demonstrated that ATRX establishes a functional interaction with the cohesin proteins (SMC1/SMC3), the methyl cytosine binding protein MeCP2 as well as the chromatin insulator CTCF to regulate histone modifications as well as expression patterns at a subset of imprinted genes in the mouse brain (Kernohan et al. 2010). Mutations in human SMC1A and SMC3 result in
Cornelia de Lange syndrome, and abnormal MeCp2 function is associated with Rett syndrome. Both conditions exhibit a neurodevelopmental phenotype. Notably, studies suggest that ATRX might control the expression of select imprinted genes in the brain through a potential role in modulating chromatin loop formation and large-scale chromatin structure (Kernohan et al. 2010). This is consistent with its role in the neuropathogenesis of ATRX syndrome in which spontaneous mutations result in several degrees of mental retardation in humans and reduced cortical size in the brain of mice with a conditional deletion (Bérubé et al. 2002, 2005).

Surprisingly, identical ATRX mutations in different patients can result in variable hematological and neurological phenotyes (Gibbons et al. 2003, 2008). While the molecular mechanisms involved in this process remained obscure for some time, recent analysis of genome-wide binding sites in mouse and human cells using chromatin immunoprecipitation (ChIP) sequencing has provided intriguing evidence that ATRX is enriched at variable number tandem repeats (VNTRs). The size of VNTR elements varies among different individuals. Therefore, the different phenotypes observed in patients carrying the same mutation might be explained by variation in the size of the tandem repeats affected in different patients (Law et al. 2010).

In addition to its prominent role in the control of transcription at specific loci, ATRX regulates chromatin structure and function at both centromeric heterochromatin and telomeric domains. For example, ATRX binds pericentric heterochromatin through a direct interaction of its ADD domain with histone $\mathrm{H} 3$ methylated at lysine 9 (H3K9me3; Dhayalan et al. 2011). Notably, ATRX establishes a functional interaction with the transcriptional regulator DAXX at pericentric heterochromatin as well as at promyelocytic leukemia nuclear bodies (Tang et al. 2004a), where it is part of a protein complex with chromatin remodeling activity (Xue et al. 2003). The ATRX-DAXX complex plays a critical role in the replication-independent deposition of the histone variant H3.3, functioning as a bona fide histone chaperone at specific genomic regions including telomeric domains (Drane et al. 2010, Goldberg et al. 2010, Lewis et al. 2010). ATRX also interacts with canonical telomeric DNA sequences where, in addition to its role in deposition of H3.3, it is essential for the maintenance of transcriptional repression of telomeric RNA in mouse and human ES cells (Goldberg et al. 2010, Wong et al. 2010). Importantly, functional ablation of ATRX induced changes in chromatin composition and telomere instability in mouse ES cells (Wong et al. 2010).

Consistent with these observations, several lines of evidence indicate that ATRX plays a prominent role in the maintenance of chromosome stability in mammalian somatic and germ cells. For instance, RNAi knockdown in mouse oocytes induced abnormal chromosomemicrotubule interactions and defects in meiotic spindle 
formation at the metaphase II stage of meiosis (De La Fuente et al. 2004). In addition, lack of ATRX function in HeLa cells results in severe chromosome cohesion and congression defects (Ritchie et al. 2008). Furthermore, our recent studies indicate that lack of ATRX function in the female germ line interferes with the establishment of epigenetic modifications associated with chromosome condensation and centromere stability resulting in the transmission of aneuploidy during the transition to the first mitosis. Importantly, ATRX plays a direct role in recruiting the transcriptional regulator DAXX to pericentric heterochromatin domains in the oocyte genome (Baumann et al. 2010). The type of chromosome segregation defects found in ATRX-deficient oocytes, namely premature centromere separation and chromosome non-disjunction, are also the two most common causes of aneuploidy in oocytes from women of advance reproductive age (Vialard et al. 2006). Hence, ATRXdeficient ova constitute an invaluable model to determine the epigenetic origins of aneuploidy in mammalian oocytes. Collectively, these results indicate that ATRX plays a critical role in the maintenance of chromosome stability during mitosis as well as meiosis (De La Fuente et al. 2004, Ritchie et al. 2008, Baumann et al. 2010).

Notably, almost $80 \%$ of patients with ATRX syndrome exhibit urogenital abnormalities ranging from undescended testes, testicular dysgenesis, and in extreme cases male to female sex reversal. The spectrum of abnormalities encountered in these patients is strongly suggestive of a potential role in sexual differentiation, although the mechanisms involved in this process remain to be elucidated (Tang et al. 2004b, Gibbons et al. 2008). ATRX associates with pericentric heterochromatin as well as with the $\mathrm{Y}$ chromosome on mouse neonatal spermatogonia (Baumann et al. 2008) and is present in both somatic and germ cells of adult rat and human testes (Tang et al. 2011), where it establishes a physical interaction with the androgen receptor and is required for Sertoli cell proliferation (Bagheri-Fam et al. 2011).

Most importantly, intriguing new evidence indicates that ATRX expression and function might be abnormally regulated in several types of cancers (Gibbons et al. 2003, Haas et al. 2009, Steensma et al. 2009, Elsasser et al. 2011, Jiao et al. 2011). Mutations in the PHD domain of this protein exacerbate the hematopoietic phenotype in premalignant conditions such as myelodysplastic syndrome (Gibbons et al. 2003). In addition, abnormal ATRX gene expression patterns have recently been observed in acute myeloid leukemia (AML; Serrano et al. 2006), where AML patients with reduced ATRX expression exhibit karyotypic abnormalities (Serrano et al. 2006). Moreover, genome-wide analysis of somatic mutations by exome sequencing in human tumors revealed that frameshifts and non-sense mutations in chromatin remodeling proteins, including ATRX, are frequently observed in pancreatic neuroendocrine tumors (Elsasser et al. 2011, Jiao et al. 2011). This results in complete loss of DAXX or ATRX function in $43 \%$ of cancers characterized by high levels of chromosome instability (Jiao et al. 2011).

\section{ATRX is an epigenetic marker of the murine inactive $X$ chromosome}

ATRX is the first member of the SWI2/SNF2 family of chromatin remodeling proteins to be detected in association with facultative heterochromatin on the inactive $X$ chromosome (Baumann \& De La Fuente 2009). ATRX remains stably associated with Xi during interphase as well as metaphase where it exhibits a banding pattern along the entire inactive $\mathrm{X}$ chromosome in mouse ovarian granulosa cells, embryonic fibroblasts as well as trophoblast stem (TS) cells, suggesting a potential involvement in XCI (Fig. 1). ChIP in mouse embryonic fibroblasts indicates that ATRX is preferentially enriched at the $\mathrm{H} 3 \mathrm{~K} 9 \mathrm{me}$ hot spot similar to bona fide markers of the inactive $X$ such as $\mathrm{H} 3 \mathrm{~K} 9 \mathrm{me} 2$ and H3K27me3 (Baumann \& De La Fuente 2009). Moreover, ATRX co-localizes with macroH2A on a late replicating $X$ chromosome (Baumann \& De La Fuente 2009). The specific role(s) of ATRX in dosage compensation is not clear at present. However, several lines of evidence indicate that ATRX might be involved in the maintenance rather than the onset of $\mathrm{XCl}$. For example, although the association of ATRX to the H3K9me hot spot can be initially detected by ChIP assays on day 5 of embryonic stem (ES) cell differentiation (Baumann \& De La Fuente 2009), a significant enrichment of this chromatin remodeling factor as well as its chromosome-wide distribution over the $\mathrm{Xi}$ is not detected until day 8 following spontaneous differentiation (Baumann \& De La Fuente 2009). Notably, conditional deletion of ATRX in the mouse preimplantation embryo interferes with imprinted inactivation of the paternal $X$ chromosome in extraembryonic tissues and severely disrupts trophoblast giant cell formation following implantation indicating a prominent role for ATRX in trophoblast development (Garrick et al. 2006).

The patterns of Atrx gene expression during preimplantation development in mice suggest the existence of diverse requirements for dosage compensation for X-linked genes in different tissues. For example, Atrx becomes inactivated in the epiblast by the blastocyst stage but subsequently escapes $\mathrm{XCl}$ in extraembryonic tissues (Garrick et al. 2006, Patrat et al. 2009). This indicates that escape from $\mathrm{XCl}$ for this factor occurs on a tissue-specific manner following implantation. Expression of Atrx in the trophoblast may, therefore, be required for the $\mathrm{XCl}$ process in placental derivatives during mammalian development (Garrick et al. 2006, Patrat et al. 2009). However, further studies are required to determine whether ATRX is strictly necessary for 

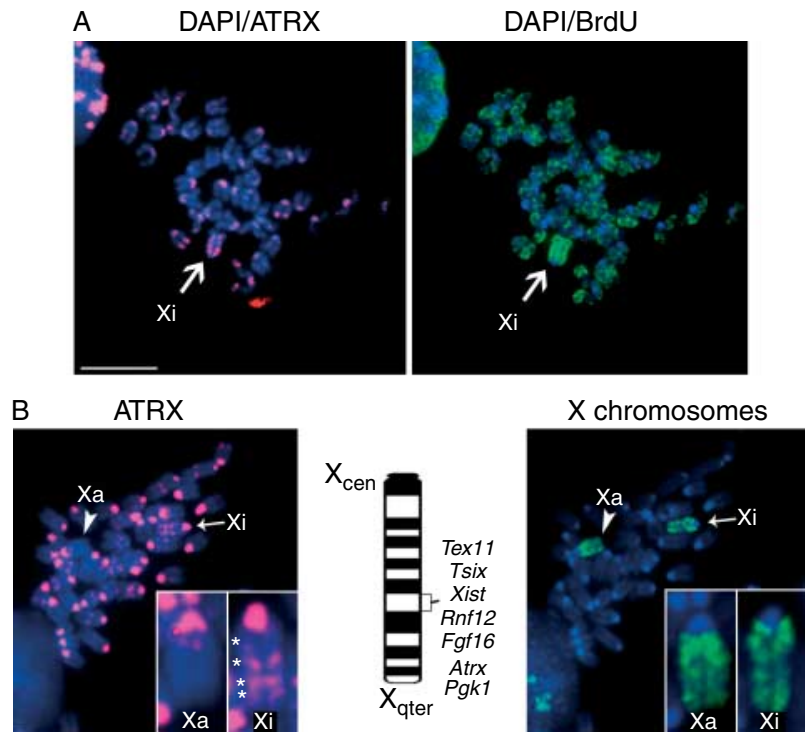

Figure 1 ATRX accumulates in a non-linear banding pattern along the chromatids of the inactive $X$ chromosome. (A) In addition to its prominent association with pericentric heterochromatin, ATRX (red) decorates the inactive $\mathrm{X}$ chromosome (Xi; arrow) in metaphase spreads from diploid trophoblast stem (TS) cells. Preferential association of $\mathrm{BrdU}$ (green) on the allocyclic replicating Xi is confirmed on the same metaphase spread. (B) Immuno-FISH analysis using an X chromosome painting probe confirmed that ATRX is preferentially enriched at one of the two X chromosomes in TS cells. Up to four ATRX bands are detectable on the Xi (inset), whereas Xa exhibits ATRX staining only at pericentric heterochromatin (inset). The ideogram represents a characteristic Giemsa staining pattern. The approximate localization of the murine Xist locus as well as additional X-linked genes including Atrx is indicated.

global transcriptional silencing of the inactive $X$ chromosome in the epiblast, as well as to elucidate the specific roles of this chromatin remodeling protein in the maintenance of imprinted $\mathrm{XCl}$.

\section{Comparative aspects of $\mathrm{XCI}$}

In mammals, the process of dosage compensation takes place through the transcriptional inactivation of one of the two $X$ chromosomes during early embryonic development (Lyon 1961). This process is thought to have evolved $\sim 150$ million years ago and is conserved among female mammals (Deakin et al. 2009). However, the molecular mechanisms controlling $\mathrm{XCl}$ as well as the type and number of genes subject to inactivation differ significantly between human and mouse (Okamoto \& Heard 2009, Berletch et al. 2010, Okamoto et al. 2011).

Inactivation of one of the two $X$ chromosomes in female mammals is an essential process for normal embryogenesis as functional uniparental disomy for the $\mathrm{X}$ chromosomes results in embryonic mortality (Takagi \& Abe 1990, Migeon et al. 1993, Marahrens et al. 1997). A major breakthrough towards the molecular analysis of $\mathrm{XCl}$ came with the isolation and cloning of a non-coding
RNA expressed exclusively from the inactive $X$ chromosome, the $X$ inactive-specific $(X I S T)$ transcript. Its location and exclusive expression from the inactive $X$ chromosome in both human and mouse somatic cells suggested a role in dosage compensation (Borsani et al. 1991, Brockdorff et al. 1991, Brown et al. 1991). Since its initial identification, the process of $\mathrm{XCl}$ has emerged as one of the prime examples of an epigenetic mechanism capable of regulating gene expression in response to critical developmental transitions. Importantly, accumulating evidence also indicates the existence of a link between $\mathrm{XCl}$ and the maintenance of chromosome stability in several human diseases including breast and ovarian cancer (Pageau et al. 2007, Agrelo \& Wutz 2009, Hall et al. 2009).

The underlying molecular mechanisms involved in the regulation of $\mathrm{XCl}$ in mice have been the subject of intense investigation and are reviewed in detail elsewhere (Clerc \& Avner 2003, Payer \& Lee 2008, Barakat et al. 2010). However, comparative analysis of XCl reveals prominent differences in the molecular mechanisms and developmental regulation of dosage compensation between human and mouse (Okamoto \& Heard 2009, Chang \& Brown 2010, Okamoto et al. 2011).

Nucleotide sequence analysis revealed that the XIST/Xist transcript consists of a $17 \mathrm{~kb}$ nucleotide sequence in human and $15 \mathrm{~kb}$ in mouse, which exhibit no protein coding potential (Brockdorff et al. 1992, Brown et al. 1992). The number and orientation of exons varies between species; however, a highly conserved sequence has been detected at the most $5^{\prime}$ region of exon 1 in several mammals suggesting an important functional role of this region for the onset of XCI (Hendrich et al. 1993). Elegant studies subsequently led to the identification of additional regulatory elements at the $\mathrm{XCl}$ center (XIC) in mice and revealed the presence of a complex multifunctional locus controlling the expression of several key regulatory and non-coding RNAs that are essential for i) counting the number of $X$ chromosomes per diploid genome, ii) determining which $X$ chromosome will become inactive (choice), and iii) regulating the initiation and spreading of the inactivation process throughout an entire $X$ chromosome following a developmental transition (Lee \& Lu 1999, Lee et al. 1999, Ogawa \& Lee 2003, Stavropoulos et al. 2005, Bacher et al. 2006, Augui et al. 2007, Navarro et al. 2008, Lee 2009). However, while the critical 5' region of Xist has been evolutionarily conserved between human and mouse, many of the regulatory elements found downstream from the murine Xist sequence are not conserved in human XIC (Chang \& Brown 2010). Moreover, $\mathrm{XCl}$ in marsupials takes place in the absence of Xist expression suggesting that either an alternative non-coding RNA or prominent epigenetic mechanisms may be set in place for the onset and maintenance of $\mathrm{XCl}$ in the marsupial embryo (Mahadevaiah et al. 2009, 
Okamoto \& Heard 2009, Rens et al. 2010, Okamoto et al. 2011).

The nuclear and chromosomal localization of the Xist transcript provides a remarkable example of the role of chromatin conformation in the control of gene expression. For instance, Xist RNA remains in close apposition with the inactive $X$ chromosome, blocking the expression of most genes associated with this chromosome and contributing to the formation of a heterochromatin domain or Barr body (Brockdorff et al. 1992, Brown et al. 1992, Clemson et al. 1996). Spreading of inactivation to other genes involves chromatin changes such as global histone methylation and histone hypoacetylation (Jeppesen \& Turner 1993, Clemson et al. 1996, Marks et al. 2009).

\section{Epigenetic mechanisms of XCI}

Ectopic Xist expression in autosomes leads to gene inactivation, late replication, and chromatin remodeling by decreasing acetylation of histone $\mathrm{H} 4$ (Lee \& Jaenisch 1997, Hall et al. 2002). However, $\mathrm{XCl}$ is maintained after deletion of the XIC region indicating that the XIC is no longer required once dosage compensation is established (Brown \& Willard 1994, Csankovszki et al. 2001). These studies suggest that epigenetic modifications might be critical for the maintenance of transcriptional silencing of the inactive $X$ chromosome (Brockdorff 2002, Heard \& Disteche 2006).

During the initiation phase, between 48 and $72 \mathrm{~h}$ following ES cell differentiation, Xist RNA coating is strictly required for $\mathrm{XCl}$. In contrast, maintenance of the inactive state is independent of Xist RNA during the irreversible stage $(>72 \mathrm{~h})$ in ES cells as well as in somatic cells (Csankovszki et al. 2001, Chaumeil et al. 2006). Maintenance of $\mathrm{XCl}$ in somatic cells is, therefore, achieved through clonal inheritance of multiple epigenetic modifications and potentially reinforced by noncoding RNAs, DNA methylation, and late replication (Brown \& Willard 1994, Bernardino et al. 2000, Brockdorff 2002, Heard \& Disteche 2006). Non-coding RNAs recruit specific epigenetic marks to the active as well as the inactive $X$ chromosome and thereby establish an asymmetric chromatin environment between the two $\mathrm{X}$ chromosomes in the female embryo (Bernstein et al. 2006, Pandey et al. 2008, Kanduri et al. 2009). In addition, Xist RNA establishes a transcriptionally silent nuclear domain devoid of RNA polymerase II and transcription factors (Chaumeil et al. 2006). Although no major differences were detected between the two $X$ chromosomes at the level of the $30 \mathrm{~nm}$ chromatin fiber (Naughton et al. 2010), the complex interplay between histone modifications and chromatin remodeling factors induces dramatic changes in large-scale chromatin structure, which are also reflected by transcriptional repression as well as by transient interaction between the two X chromosomes (Xu et al. 2006, Naughton et al.
2010) and finally result in a close association of the $X i$ with heterochromatin domains around the nucleolus (Zhang et al. 2007).

The molecular composition of the large protein complexes modulating the epigenetic landscape of the human and mouse inactive $X$ chromosomes are beginning to be unraveled (Table 1). Importantly, the kinetics of changes in histone modifications as well as the recruitment of specific chromatin remodeling factors and histone variants associated with the allocyclic, heterochromatic $\mathrm{Xi}$ has been characterized following induced differentiation in ES cells (O'Neill et al. 1999, Costanzi et al. 2000, Brockdorff 2002, Heard \& Disteche 2006). These changes play distinct, albeit complementary, roles in the maintenance of transcriptional silencing (Fig. 2). Nevertheless, our understanding of the specific function of the myriad epigenetic modifications in heterochromatinization and/or maintenance of the inactive state is far from complete. For example, the mechanisms involved in recruitment of such diverse protein complexes to the inactive $\mathrm{X}$ chromosome are not fully understood, nor is it known how transcriptional repression and large-scale chromatin remodeling are coordinated to spread a heterochromatic state over an entire chromosome. Analysis of the kinetics of $\mathrm{XCl}$ after exposure of female murine ES cells to retinoic acid indicates that 'coating' of the inactive $\mathrm{X}$ chromosome by $X$ ist RNA occurs within $24-48 \mathrm{~h}$ following induction of differentiation (Heard et al. 2001) with transcriptional silencing taking place within an additional $24 \mathrm{~h}(\mathrm{Ng}$ et al. 2007). Trimethylation of histone H3 lysine 9 ( $\mathrm{H} 3 \mathrm{~K} 9 \mathrm{me} 3)$ together with histone $\mathrm{H} 4$ trimethylated at lysine 20 (H4K20me3) is one of the earliest marks to be recruited to $\mathrm{Xi}$ almost immediately following the initial $X i s t$ RNA coating and before transcriptional repression is established during a precise developmental window (Heard et al. 2001, Boggs et al. 2002, Chadwick \& Willard 2004, Chaumeil et al. 2006). Interestingly, these changes are initiated at a specific $5^{\prime}$ region to the Xist promoter, the H3K9me 'hot-spot'. This region has been suggested to act as a putative nucleation center that might recruit additional epigenetic marks (Heard et al. 2001, Silva et al. 2003, Rougeulle et al. 2004).

Transcriptionally permissive histone modifications such as acetylation of histones $\mathrm{H} 3 / \mathrm{H} 4$ are subsequently lost from the inactive $X$ chromosome on day 2.5 of differentiation followed by deposition of silent chromatin marks such as polycomb complexes and a shift to late replication by day 4 . Heterochromatinization and enrichment for histone variants such as macroH2A and chromatin remodeling proteins such as ATRX take place following day 5 of differentiation, and finally DNA methylation changes at specific promoters on day 9 of differentiation (Fig. 2; O'Neill et al. 1999, Brockdorff 2002, Heard \& Disteche 2006, Baumann \& De La Fuente 2009).

Binding of Xist RNA is thought to induce local heterochromatinization on the $\mathrm{Xi}$ by recruiting 
Table 1 Epigenetic modifications associated with the inactive $\mathrm{X}$ chromosome.

\begin{tabular}{|c|c|c|c|}
\hline Epigenetic modification & $X_{\text {inactive }}$ & $X_{\text {active }}$ & References \\
\hline \multicolumn{4}{|l|}{ Non-coding RNAs } \\
\hline Xist & + & - & Brown et al. (1992) and Clemson et al. (1996) \\
\hline Tsix & - & + & Lee et al. (1999) \\
\hline \multicolumn{4}{|l|}{ Histone variants } \\
\hline Histone $\mathrm{H} 1$ & + & - & Chadwick \& Willard (2004) ${ }^{\mathrm{a}}$ \\
\hline MacroH2A & + & - & Costanzi et al. (2000) \\
\hline \multicolumn{4}{|l|}{ Histone modifications } \\
\hline $\mathrm{ubH} 2 \mathrm{~A}$ & + & - & Fang et al. (2004) and de Napoles et al. (2004) \\
\hline H3K9me2 & + & - & Heard et al. (2001) and Boggs et al. $(2002)^{a}$ \\
\hline H3K9me3 & + & - & Chadwick \& Willard $(2004)^{\mathrm{a}}$ \\
\hline H3K4me2 & - & + & Chadwick \& Willard (2004) ${ }^{\mathrm{a}}$ \\
\hline $\mathrm{H} 3 \mathrm{~K} 27 \mathrm{me} 3$ & + & - & Plath et al. $(2003)^{\mathrm{a}}$ \\
\hline H4 hypoacetylation & + & - & Jeppesen \& Turner (1993) a and O'Neill et al. (1999) \\
\hline \multicolumn{4}{|l|}{ Polycomb proteins } \\
\hline RING1A/B & + & - & Fang et al. (2004) and de Napoles et al. (2004) \\
\hline PHC1, $\mathrm{PHC} 2$ & + & - & Plath et al. $(2004)^{\mathrm{a}}$ \\
\hline $\mathrm{EED} / \mathrm{EZH} 2$ & + & - & Mak et al. (2002), Plath et al. (2003) ${ }^{\mathrm{a}}$ and Silva et al. (2003) \\
\hline CBX6, CBX7, CBX8 & + & - & Bernstein et al. (2006) \\
\hline $\mathrm{CBX} 2$ & + & - & Plath et al. (2004) a and Bernstein et al. (2006) \\
\hline BMI1 & + & - & Plath et al. $(2004)^{\mathrm{a}}$ \\
\hline ASH2L & + & - & Pullirsch et al. (2010) ${ }^{\mathrm{a}}$ \\
\hline \multicolumn{4}{|l|}{ Chromatin remodelling } \\
\hline ATRX & + & - & Baumann \& De La Fuente (2009) \\
\hline \multicolumn{4}{|l|}{ Tumor suppressor } \\
\hline BRCA1 & + & - & Ganesan et al. (2002) ${ }^{a}$ \\
\hline \multicolumn{4}{|l|}{ Others } \\
\hline PARP1 & + & - & Nusinow et al. $(2007)^{\mathrm{a}}$ \\
\hline HP1 & + & - & Chadwick \& Willard (2004) ${ }^{\mathrm{a}}$ \\
\hline SAF-A & + & - & Helbig \& Fackelmayer (2003) and Pullirsch et al. (2010) \\
\hline SMCHD1 & + & - & Blewitt et al. (2008) \\
\hline \multicolumn{4}{|l|}{ DNA methylation } \\
\hline Global (chromosome-wide) & - & + & Bernardino et al. $(2000)^{\mathrm{a}}$ \\
\hline Promoter regions & + & - & Mohandas et al. (1981) and Hellman \& Chess (2007) ${ }^{a}$ \\
\hline
\end{tabular}

+ , enrichment; - , absence.

${ }^{a}$ Conserved in the human inactive $X$.

transcriptionally repressive protein complexes that spread in cis throughout the entire $\mathrm{X}$ chromosome. For example, a high resolution comprehensive map of local chromatin modifications at regulatory sequences within the XIC revealed that following the onset of Xist expression, a chromosome-wide increase in the levels of H3K27me3 is detected exclusively on the inactive $X$ chromosome. Moreover, spreading of this epigenetic mark is associated with transcriptional silencing of most genes associated with the Xi (Marks et al. 2009). A $1.6 \mathrm{~kb}$ regulatory transcript $(\operatorname{RepA})$ might also contribute to chromosome-wide silencing by facilitating the association of the inactive $X$ chromosome with heterochromatin domains in the nucleus and by recruiting members of the polycomb repressive complex (PRC2) to the $\mathrm{Xi}$ (Chaumeil et al. 2006, Zhang et al. 2007, Pullirsch et al. 2010). Further studies are required to determine the precise mechanisms involved in translating a local epigenetic change at specific regulatory sequences of the XIC into chromosome-wide transcriptional silencing. However, facultative heterochromatin formation might be an essential mechanism in this process (Helbig \& Fackelmayer 2003, Trojer \& Reinberg 2007, Marks et al. 2009). Together with Xist RNA, long interspersed nuclear elements (LINES) contribute to the spreading of transcriptional silencing by creating a transcriptionally repressive chromatin environment rich in repetitive elements that in concert with the SATB1 protein function to nucleate heterochromatin formation at several regions throughout the inactive $\mathrm{X}$ chromosome (Agrelo et al. 2009, Chow et al. 2010).

Some epigenetic marks including ATRX are present in both pericentric heterochromatin of autosomes and heterochromatin at the inactive $X$ chromosome. Interestingly, several ubiquitinated proteins such as ubiquitinated histone $\mathrm{H} 2 \mathrm{~A}(\mathrm{ubH} 2 \mathrm{~A})$ exhibit an exclusive association with the inactive $X$ chromosome in somatic cells where it is present in a banding pattern that co-localizes with segments of Xist RNA on early mitotic chromosomes (Wang et al. 2001, Fang et al. 2004, de Napoles et al. 2004, Smith et al. 2004). Notably, recent studies have indicated that both ubiquitination and the enzymatic activity of Aurora B kinase are essential to recruit human XIST RNA to multiple binding sites in somatic cells (Hall et al. 2009). In turn, histone ubiquitination can induce additional post-translational modifications that might be of functional significance for the spreading of chromosome-wide transcriptional 


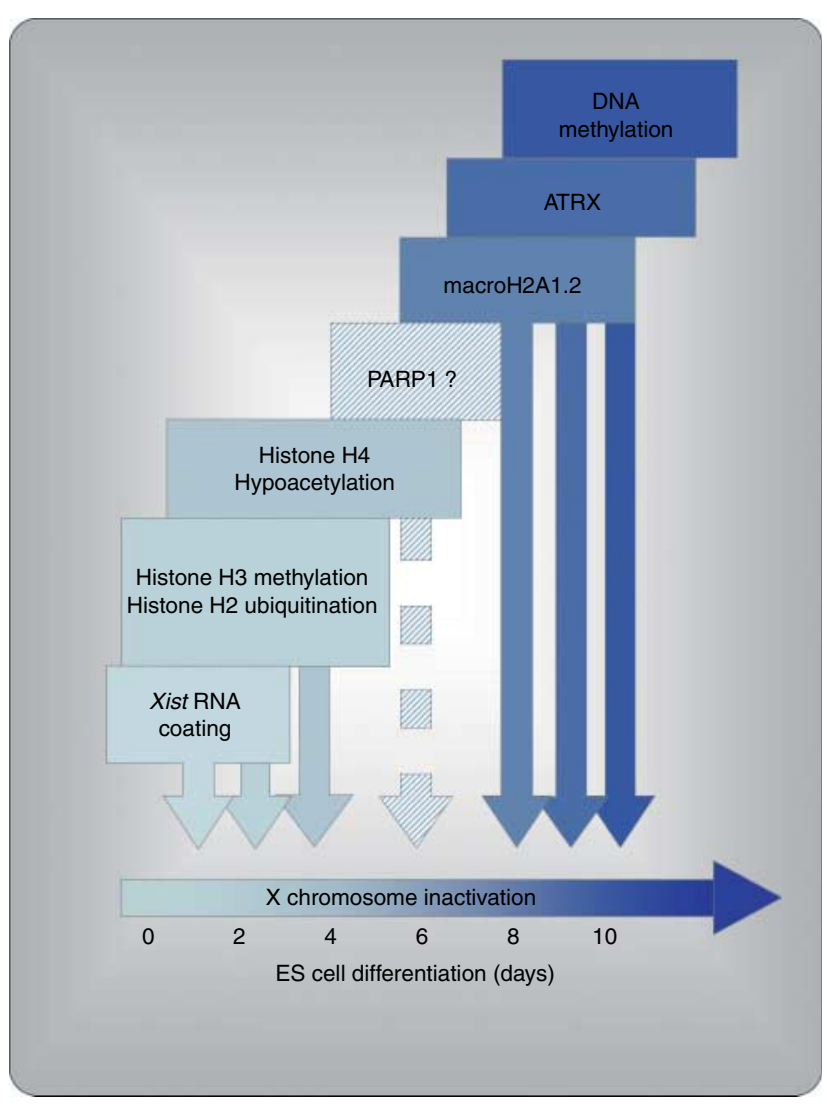

Figure 2 Kinetics of epigenetic modifications imposed on the inactive $X$ chromosome $(\mathrm{Xi})$ following spontaneous differentiation of mouse embryonic stem (ES) cells. Time line of chromosome-wide association for different histone modifications, histone variants, and chromatin remodeling proteins known to contribute to the epigenetic landscape of Xi. Multiple epigenetic marks participate in the process of heterochromatinization and transcriptional silencing. Different shades of blue indicate the progressive transition from chromatin modifications involved in the onset versus the maintenance of the inactive state.

silencing (Smith et al. 2004). Although an attractive model, the transient nature of ubH2A staining during the early stages of XCl in TS cells (Fang et al. 2004) indicates that additional factors may be involved in maintaining the heterochromatic state following ES and TS cell differentiation (Hall et al. 2009). Interestingly, elegant studies in mouse ES cells have recently implicated the E3 ubiquitin ligase RNF12 as the first protein factor with a dose-dependent role in the initiation of $\mathrm{XCl}$. However, the mechanisms involved in this process are yet to be determined (Jonkers et al. 2009).

Members of the PRC1 proteins such as BMI1, RNF2/RING1B, and CBX4 as well as the histone variant macroH2A 1 are recruited to the inactive $X$ chromosome in a cell cycle-dependent manner following ubiquitination by the CULLIN3/SPOP ubiquitin E3 ligase, where they play a role in the maintenance of $\mathrm{XCI}$ in somatic cells (Hernandez-Munoz et al. 2005). RING1B may also compact chromatin through a mechanism independent of histone ubiquitination (Eskeland et al. 2010).
MacroH2A interferes with transcription factor binding as determined by in vitro-reconstituted chromatin assays and inhibits the activity of chromatin remodeling proteins (Trojer \& Reinberg 2007). Moreover, macroH2A may induce chromatin compaction by inhibiting the enzymatic activity of the poly (ADP-ribose) polymerase1 (PARP1) protein, thus providing critical insight into the potential mechanisms of macroH2 $\mathrm{A}$ as a transcriptionally repressive mark on the inactive $X$ chromosome (Ouararhni et al. 2006, Nusinow et al. 2007, Trojer \& Reinberg 2007, Timinszky et al. 2009).

PARP1 is a NAD ${ }^{+}$-dependent chromatin remodeling protein that becomes quickly activated in response to DNA damage by direct binding to double strand breaks (DSBs) through its zinc finger domains (Kim et al. 2004, 2005). Nevertheless, compelling evidence indicates that this protein might also be an important regulator of chromatin modifications under physiological conditions. For example, in both human and Drosophila cells, PARP1 activation resulting from nucleosome binding may induce the reversible modulation of chromatin structure during key developmental transitions in the absence of DNA damage (Tulin et al. 2002, Tulin \& Spradling 2003, Kim et al. 2004). Notably, PARP1 has recently been found localized to the inactive $X$ chromosome in a somatic cell line, in which macroH2A1.2-GFP is specifically overexpressed at $\mathrm{Xi}$. In this model, PARP1 is required for the maintenance of transcriptional silencing of a reporter transgene providing the first evidence indicating a potential role for PARP1 in maintaining a transcriptionally repressive chromatin environment during $\mathrm{XCl}$ (Nusinow et al. 2007). Consistent with this hypothesis, our recent studies have indicated that PARP1 is a stable epigenetic mark on the inactive $X$ chromosome during both interphase (Fig. 3A) and metaphase stages (Fig. 3B) in primary mouse embryonic fibroblasts.

\section{Abnormalities of XCI: implications for chromosome instability}

In principle, the $\mathrm{XCl}$ process can potentially be disrupted by environmental, toxicological, and/or disease conditions that affect i) chromatin structure and function, or ii) disrupt the establishment and/or maintenance of epigenetic modifications (Hall et al. 2009). In turn, abnormalities on $X$ chromosome ploidy or epigenetic stability may lead to disease conditions arising from abnormal X-linked gene dosage. Specifically, recent studies have indicated that XIST function may be severely affected by defects in heterochromatin stability and large-scale chromatin structure in several types of human primary cell tumors (Pageau et al. 2007, Hall et al. 2009). Since the initial observations on the loss of the Barr body in breast and ovarian cancer cells five decades ago, studies have established that errors in chromosome segregation result in a high proportion of 


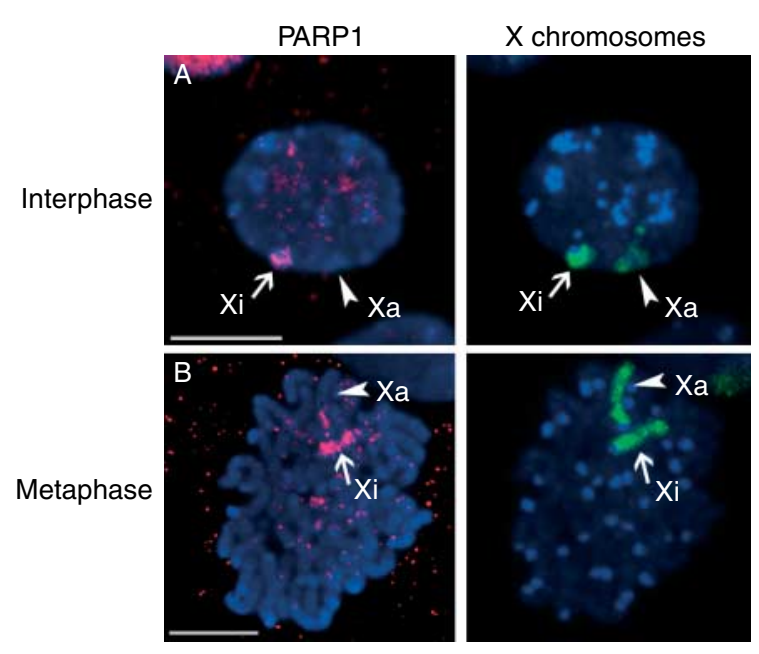

Figure 3 Stable association of the poly (ADP-ribose) polymerase-1 (PARP1) protein with the inactive $X$ chromosome $X i$ in mouse embryonic fibroblasts (MEFs) during interphase and metaphase. PARP1 (red) is co-localized with a condensed heterochromatic nuclear domain corresponding to the inactive $\mathrm{X}$ chromosome (Xi) or Barr body as detected by fluorescence in situ hybridization (green). PARP1 (red) decorates both chromatids on Xi (arrows) during mitosis. DNA is stained in blue (DAPI).

malignant cells lacking an inactive $\mathrm{X}$ chromosome. The most common mechanism involved in this process induces the formation of uniparental disomy for the active $X$ chromosome as a consequence of nondisjunction resulting in the emergence of cells carrying two genetically identical $X$ chromosomes (Pageau et al. 2007). Alternatively, abnormal epigenetic modifications commonly observed during malignant neoplastic transformation may lead to reactivation of the inactive $\mathrm{X}$ chromosome by disrupting the cascade of chromatin changes leading to heterochromatinization of large chromosomal segments or even an entire $\mathrm{X}$ chromosome (Pageau et al. 2007). Importantly, these mechanisms are not mutually exclusive and may occur in the same nucleus, leading to the clonal inheritance of malignant cells and subsequent tumor formation (Pageau et al. 2007). For example, functional ablation of the tumor suppressor BRCA1 might predispose cells to epigenetic instability and defects in DNA repair resulting in the formation of chromosomal rearrangements capable of interfering with XCI (Ganesan et al. 2002). Interestingly, some breast cancer cell lines as well as primary breast tumors exhibit improper localization of Xist RNA associated with abnormal heterochromatin formation (Pageau et al. 2007, Vincent-Salomon et al. 2007). In turn, abnormal heterochromatin formation might promote global changes in gene expression leading to chromosome instability and malignant neoplastic transformation (Pageau et al. 2007).

Notably, $\mathrm{X}$ chromosome instability was observed in female mice heterozygous for Parp1 that also carry a homozygous deletion of Parp2 (Parp1 $1^{+/} /$Parp $\left.^{-/-}\right)$. In these mice, $\sim 40 \%$ of female, but not male, embryonic fibroblast cells exhibit aneuploidy specific to the $X$ chromosome (Ménissier de Murcia et al. 2003). Consistent with these studies, we have recently observed indicators of $\mathrm{X}$ chromosome instability in oocytes obtained from Parp1 knockout female mice during the prophase I of meiosis (Yang et al. 2009). For example, analysis of homologous chromosome synapsis in fetal oocytes revealed a striking accumulation of RAD51 protein, a DNA recombination intermediate associated with DSBs formation (Moens et al. 2002, Burgoyne et al. 2007), at the meiotic chromosome cores of the fully synapsed X chromosome bivalent (Yang et al. 2009; Fig. 4). This indicates the presence of unresolved double strand DNA breaks in Parp1 null oocytes at the pachytene stage, a time at which DSBs are fully repaired in control oocytes. Importantly, the $\mathrm{X}$ chromosome bivalent also exhibits abnormal chromatin modifications as detected by persistence of histone H2AX phosphorylation (Yang et al. 2009). The mechanisms involved in failure to repair DSBs in this model warrant further investigation. However, this might result from an increased susceptibility of the $X$ chromosome bivalent to illegitimate recombination and, potentially, a contributing factor to the $\mathrm{X}$ chromosome instability reported in Parp $1^{+/-} /$Parp $^{-1-}$ female mice (Ménissier de Murcia et al. 2003).

Epigenetic instability on the inactive $X$ chromosome has also been observed in human ES cells where a vast proportion of established cell lines exhibit an inactive $X$ chromosome before induced cell differentiation with variable levels of Xist expression and loss of H3K27me3 (Hall et al. 2008, Silva et al. 2008). Epigenetic modifications are crucial to maintain cellular identity and $\mathrm{XCl}$ is closely linked to ES differentiation. Hence,
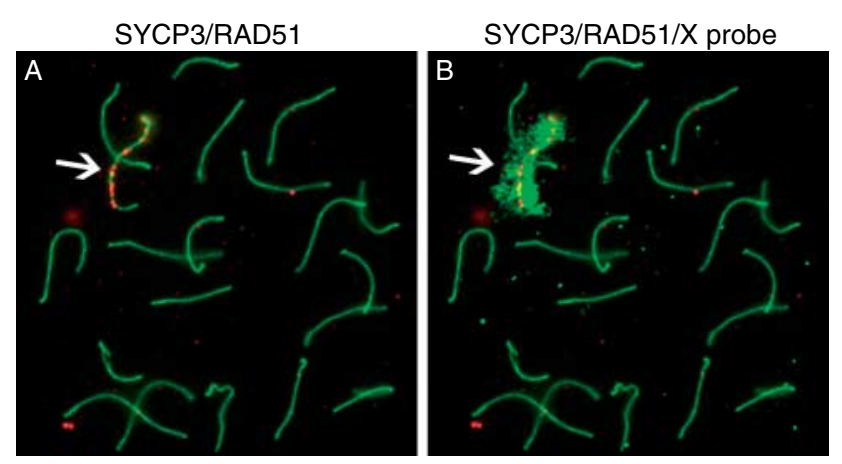

Figure 4 Persistence of RAD51 foci and genome instability at the $X$ chromosome bivalent in Parp1 null oocytes. (A) Pachytene stage oocyte with fully synapsed chromosomes labeled with the synaptonemal complex protein SYCP3 (green). Lack of PARP1 function during meiosis results in the persistence of double strand DNA breaks (RAD51 foci; red) in a single chromosome bivalent corresponding to the $\mathrm{X}$ chromosome (arrow) as determined by fluorescence in situ hybridization with an $\mathrm{X}$ chromosome probe (B; green). 
a deeper understanding of the epigenetic mechanisms involved in $\mathrm{XCl}$ is needed to design optimal culture conditions that ensure the maintenance of the undifferentiated state, the timely onset of $\mathrm{XCl}$ upon cell differentiation as well as the potential therapeutic value of human ES cells (Lengner et al. 2010).

\section{Abnormalities of XCI: implications for human disease}

To date, more than $300 \mathrm{X}$-linked genes have been associated with human pathological conditions ranging from skin disease (Sun \& Tsao 2008), renal dysfunction (Migeon 2008), and autoimmune conditions such as systemic lupus erythematosus (Pan \& Sawalha 2009) in which the patterns of random and or skewed $\mathrm{XCl}$ may have a profound influence on the clinical manifestation; for example, the early onset and/or severity of the disease (Migeon 2006). Moreover, abnormal XCl and lack of Xist transcription in patients with tiny ring $\mathrm{X}$ chromosomes result in a range of developmental and cognitive phenotypes including severe mental retardation (Migeon et al. 1993). Therefore, the initiation and maintenance of dosage compensation is a critical developmental transition with important clinical implications. Positive dosage compensation with transcriptional upregulation of a select group of genes on the active $X$ chromosome is also a phenomenon of increasing importance due to the high levels of X-linked gene expression in both male and female brain tissue, in which up to 1300 loci exhibit parent of origin allelic expression patterns. Thus, skewing of $\mathrm{XCl}$ may have a significant impact on cognitive function (Nguyen \& Disteche 2006, Hellman \& Chess 2007, Gregg et al. 2010a, 2010b). Notably, $\alpha$-thalassemia myelodisplastic syndrome (ATMDS) is a severe form of $\alpha$-thalassemia resulting from acquired mutations in ATRX. This condition contrasts with the mild forms of $\boldsymbol{\alpha}$-thalassemia detected in patients with inherited mutations of the same amino acid sequence of ATRX and indicates that in addition to the initial mutation, an epigenetic component might play a critical role in mediating the severity of the hematological phenotype (Steensma et al. 2004, 2005). Although the majority of patients diagnosed with ATMDS are male, this condition may also occur sporadically in females (Haas et al. 2009). Preliminary analysis on the patterns of $\mathrm{XCl}$ in these patients revealed no overt alterations in this process. However, further studies are required to determine the behavior of the inactive $X$ chromosome in female patients with myelodisplastic syndrome (Haas et al. 2009).

\section{Concluding remarks}

A growing body of evidence indicates that disruption of the epigenetic mechanisms involved in $\mathrm{XCl}$ may also have direct and wide-ranging implications in human health. For example, loss of transcriptionally repressive heterochromatin marks on the $\mathrm{Xi}$ such as $\mathrm{H} 3 \mathrm{~K} 27 \mathrm{me} 3$ has been observed in human fibroblasts obtained from patients with Hutchinson-Gilford progeria syndrome, a devastating condition inducing premature aging (Shumaker et al. 2006). Functional ablation of macroH2A1, another epigenetic marker of $\mathrm{Xi}$, induces a metabolic disorder characterized by hepatic steatosis and upregulation of thyroxine-binding globulin, an X-linked enzyme in female mice (Boulard et al. 2010). Importantly, loss of the AT binding protein SATB1 in lymphoma cells interferes with the ability of Xist to induce transcriptional silencing and implicates SATB1 as an important factor in the $\mathrm{XCl}$ pathway (Agrelo et al. 2009). Expression of SATB1 and certain isoforms of macroH2A1 also associates with aggressive types of breast and lung cancer respectively, and hence might prove to be valuable biomarkers in clinical oncology (Agrelo \& Wutz 2009, Agrelo et al. 2009, Sporn et al. 2009). These models provide direct evidence that the process of $\mathrm{XCl}$ has important implications for genome stability during cancer development as epigenetic regulatory pathways established in the developing conceptus may show reactivation and/or dysregulation during the complex process of malignant neoplastic transformation. Importantly, the presence of an unmethylated XIST promoter has been suggested as a potential marker for tumor progression (Kawakami et al. 2004). As we gain a better understanding of the epigenetic mechanisms regulating $\mathrm{XCl}$ and its impact on cellular differentiation, the clinical implications of this process will no doubt become increasingly appreciated.

Mutations in genes encoding for chromatin remodeling proteins containing a PHD result in a spectrum of human disorders ranging from neurodevelopmental syndromes, autoimmune conditions, myeloid leukemia, and other types of cancer (Baker et al. 2008). Among these, ATRX has recently emerged as a major epigenetic factor involved in transcriptional regulation, nuclear architecture, and chromosome stability in mammalian cells. Although ATRX was initially described as a critical transcriptional regulator of $\beta$-globin gene expression, major discoveries on the biological significance of ATRX have revealed important functions in the control of centromere and telomere stability, chromosome cohesion, and regulation of several imprinted genes in the postnatal mouse brain. Insight into the molecular mechanisms of ATRX function and its interacting partners in different tissues will no doubt contribute to our understanding of the pathogenesis of ATRX syndrome as well as the epigenetic origins of aneuploidy during development and differentiation. Altered chromatin states are a prominent hallmark of cancer cells (Davis \& Brachmann 2003, Feinberg et al. 2006). Notably, loss of epigenetic marks in progeria can be rescued by epigenetic therapy (Columbaro et al. 2005). This provides encouraging evidence for the identification 
of chromatin remodeling proteins as potential drug targets as well as the rational design of novel therapeutic management strategies of the abnormal epigenetic profiles observed during malignant neoplastic transformation.

\section{Declaration of interest}

The authors declare that there is no conflict of interest that could be perceived as prejudicing the impartiality of this review.

\section{Funding}

Research in the author's laboratory is supported by grants from the National Institutes of Health (NICHD): 2RO1-HDO42740 and the Georgia Cancer Coalition. We apologize to colleagues whose work could not be cited due to space limitations.

\section{References}

Agrelo R \& Wutz A 2009 X inactivation and disease. Seminars in Cell \& Developmental Biology 21 194-200. (doi:10.1016/j.semcdb.2009. 09.017)

Agrelo R, Souabni A, Novatchkova M, Haslinger C, Leeb M, Komnenovic V, Kishimoto H, Gresh L, Kohwi-Shigematsu T, Kenner L et al. 2009 SATB1 defines the developmental context for gene silencing by Xist in lymphoma and embryonic cells. Developmental Cell 16 507-516. (doi:10.1016/j.devcel.2009.03.006)

Argentaro A, Yang J, Chapman L, Kowalczyk M, Gibbons R, Higgs D, Neuhaus D \& Rhodes D 2007 Structural consequences of diseasecausing mutations in the ATRX-DNMT3-DNMT3L (ADD) domain of the chromatin-associated protein ATRX. PNAS 104 11939-11944. (doi:10.1073/pnas.0704057104)

Augui S, Filion GJ, Huart S, Nora E, Guggiari M, Maresca M, Stewart AF \& Heard E 2007 Sensing X chromosome pairs before X inactivation via a novel X-pairing region of the Xic. Science 318 1632-1636. (doi:10.1126/ science.1149420)

Bacher CP, Guggiari M, Brors B, Augui S, Clerc P, Avner P, Eils R \& Heard E 2006 Transient colocalization of $\mathrm{X}$-inactivation centres accompanies the initiation of X inactivation. Nature Cell Biology 8 293-299. (doi:10.1038/ncb1365)

Badens C, Martini N, Courrier S, DesPortes V, Touraine R, Levy N \& Edery P 2006 ATRX syndrome in a girl with a heterozygous mutation in the ATRX $\mathrm{Zn}$ finger domain and a totally skewed X-inactivation pattern. American Journal of Medical Genetics. Part A 140 2212-2215. (doi:10.1002/ajmg. a.31400)

Bagheri-Fam S, Argentaro A, Svingen T, Combes AN, Sinclair AH, Koopman P \& Harley VR 2011 Defective survival of proliferating Sertoli cells and androgen receptor function in a mouse model of the ATR-X syndrome. Human Molecular Genetics 20 2213-2224. (doi:10.1093/ hmg/ddr109)

Baker LA, Allis CD \& Wang GG 2008 PHD fingers in human diseases: disorders arising from misinterpreting epigenetic marks. Mutation Research/Fundamental and Molecular Mechanisms of Mutagenesis 647 3-12. (doi:10.1016/j.mrfmmm.2008.07.004)

Banaszynski LA, Allis CD \& Lewis PW 2010 Histone variants in metazoan development. Developmental Cell 19 662-674. (doi:10.1016/j.devcel. 2010.10.014)

Barakat TS, Jonkers I, Monkhorst K \& Gribnau J 2010 X-changing information on $\mathrm{X}$ inactivation. Experimental Cell Research $\mathbf{3 1 6}$ 679-687. (doi:10.1016/j.yexcr.2010.01.015)

Baumann C \& De La Fuente R 2009 ATRX marks the inactive X chromosome (Xi) in somatic cells and during imprinted $\mathrm{X}$ chromosome inactivation in trophoblast stem cells. Chromosoma 118 209-222. (doi:10.1007/s00412008-0189-x)
Baumann C, Schmidtmann A, Muegge K \& De La Fuente R 2008 Association of ATRX with pericentric heterochromatin and the $Y$ chromosome of neonatal mouse spermatogonia. BMC Molecular Biology 9 29. (doi:10.1186/1471-2199-9-29)

Baumann C, Viveiros MM \& De La Fuente R 2010 Loss of maternal ATRX results in centromere instability and aneuploidy in the mammalian oocyte and pre-implantation embryo. PLoS Genetics 6 e1001137. (doi:10.1371/journal.pgen.1001137)

Berletch J, Yanf F \& Disteche C 2010 Escape from X inactivation in mice and humans. Genome Biology 11 213. (doi:10.1186/gb-2010-11-6-213)

Bernardino J, Lombard M, Niveleau A \& Dutrillaux B 2000 Common methylation characteristics of sex chromosomes in somatic and germ cells from mouse, lemur and human. Chromosome Research 8 513-525. (doi:10.1023/A:1009271706488)

Bernstein E, Duncan EM, Masui O, Gil J, Heard E \& Allis CD 2006 Mouse polycomb proteins bind differentially to methylated histone $\mathrm{H} 3$ and RNA and are enriched in facultative heterochromatin. Molecular and Cellular Biology 26 2560-2569. (doi:10.1128/MCB.26.7.2560-2569.2006)

Bérubé N, Smeenk C \& Picketts D 2000 Cell cycle-dependent phosphorylation of the ATRX protein correlates with changes in nuclear matrix and chromatin association. Human Molecular Genetics 9 539-547. (doi:10. 1093/hmg/9.4.539)

Bérubé NG, Jagla $M$, Smeenk CA, De Repentigny $Y$, Kothary $R$ \& Picketts DJ 2002 Neurodevelopmental defects resulting from ATRX overexpression in transgenic mice. Human Molecular Genetics 11 253-261. (doi:10.1093/hmg/11.3.253)

Bérubé NG, Mangelsdorf M, Jagla M, Vanderluit J, Garrick D, Gibbons RJ, Higgs DR, Slack RS \& Picketts DJ 2005 The chromatin-remodeling protein ATRX is critical for neuronal survival during corticogenesis. Journal of Clinical Investigation 115 258-267. (doi:10.1172/JCI22329)

Blewitt ME, Gendrel A-V, Pang Z, Sparrow DB, Whitelaw N, Craig JM, Apedaile A, Hilton DJ, Dunwoodie SL, Brockdorff N et al. 2008 SmcHD1, containing a structural-maintenance-of-chromosomes hinge domain, has a critical role in X inactivation. Nature Genetics 40 663-669. (doi:10.1038/ ng.142)

Boggs BA, Cheung P, Heard E, Spector DL, Chinault AC \& Allis CD 2002 Differentially methylated forms of histone $\mathrm{H} 3$ show unique association patterns with inactive human X chromosomes. Nature Genetics 30 73-76. (doi:10.1038/ng787)

Borsani G, Tonlorenzi R, Simmler MC, Dandolo L, Arnaud D, Capra V, Grompe M, Pizzuti A, Muzny D, Lawrence C et al. 1991 Characterization of a murine gene expressed from the inactive $\mathrm{X}$ chromosome. Nature 351 325-329. (doi:10.1038/351325a0)

Boulard M, Storck S, Cong R, Pinto R, Delage H \& Bouvet P 2010 Histone variant macroH2A1 deletion in mice causes female-specific steatosis. Epigenetics \& Chromatin 3 8. (doi:10.1186/1756-8935-3-8)

Brockdorff N 2002 X-chromosome inactivation: closing in on proteins that bind Xist RNA. Trends in Genetics 18 352-358. (doi:10.1016/S01689525(02)02717-8)

Brockdorff N, Ashworth A, Kay GF, Cooper P, Smith S, McCabe VM, Norris DP, Penny GD, Patel D \& Rastan S 1991 Conservation of position and exclusive expression of mouse Xist from the inactive $\mathrm{X}$ chromosome. Nature 351 329-331. (doi:10.1038/351329a0)

Brockdorff N, Ashworth A, Kay GF, McCabe VM, Norris DP, Cooper PJ, Swift S \& Rastan S 1992 The product of the mouse Xist gene is a $15 \mathrm{~kb}$ inactive $\mathrm{X}$-specific transcript containing no conserved ORF and located in the nucleus. Cell 71 515-526. (doi:10.1016/0092-8674(92)90519-I)

Brown CJ \& Willard HF 1994 The human X-inactivation centre is not required for maintenance of $\mathrm{X}$-chromosome inactivation. Nature $\mathbf{3 6 8}$ 154-156. (doi:10.1038/368154a0)

Brown CJ, Lafreniere RG, Powers VE, Sebastio G, Ballabio A, Pettigrew AL, Ledbetter DH, Levy E, Craig IW \& Willard HF 1991 Localization of the X inactivation centre on the human $X$ chromosome in Xq13. Nature $\mathbf{3 4 9}$ 82-84. (doi:10.1038/349082a0)

Brown CJ, Hendrich BD, Rupert JL, Lafreniere RG, Xing Y, Lawrence J \& Willard HF 1992 The human XIST gene: analysis of a $17 \mathrm{~kb}$ inactive X-specific RNA that contains conserved repeats and is highly localized within the nucleus. Cell 71 527-542. (doi:10.1016/0092-8674(92)90520-M)

Burgoyne PS, Mahadevaiah SK \& Turner JM 2007 The management of DNA double-strand breaks in mitotic G(2), and in mammalian meiosis viewed from a mitotic G(2) perspective. BioEssays 29 974-986. (doi:10.1002/ bies.20639) 
Chadwick BP \& Willard HF 2004 Multiple spatially distinct types of facultative heterochromatin on the human inactive $\mathrm{X}$ chromosome. PNAS 101 17450-17455. (doi:10.1073/pnas.0408021101)

Chang S \& Brown C 2010 Identification of regulatory elements flanking human XIST reveals species differences. BMC Molecular Biology 1120. (doi:10.1186/1471-2199-11-20)

Chaumeil J, Le Baccon P, Wutz A \& Heard E 2006 A novel role for Xist RNA in the formation of a repressive nuclear compartment into which genes are recruited when silenced. Genes and Development 20 2223-2237. (doi:10.1101/gad.380906)

Chow JC, Ciaudo C, Fazzari MJ, Mise N, Servant N, Glass JL, Attreed M, Avner P, Wutz A, Barillot E et al. 2010 LINE-1 activity in facultative heterochromatin formation during X chromosome inactivation. Cell 141 956-969. (doi:10.1016/j.cell.2010.04.042)

Clemson CM, McNeil JA, Willard HF \& Lawrence JB 1996 XIST RNA paints the inactive $X$ chromosome at interphase: evidence for a novel RNA involved in nuclear/chromosome structure. Journal of Cell Biology 132 259-275. (doi:10.1083/jcb.132.3.259)

Clerc P \& Avner P 2003 Multiple elements within the Xic regulate random X inactivation in mice. Seminars in Cell \& Developmental Biology 14 85-92. (doi:10.1016/S1084-9521(02)00140-4)

Columbaro M, Capanni C, Mattioli E, Novelli G, Parnaik V, Squarzoni S, Maraldi N \& Lattanzi G 2005 Rescue of heterochromatin organization in Hutchinson-Gilford progeria by drug treatment. Cellular and Molecular Life Sciences 62 2669-2678. (doi:10.1007/s00018-005-5318-6)

Costanzi C, Stein P, Worrad DM, Schultz RM \& Pehrson JR 2000 Histone macroH2A1 is concentrated in the inactive $\mathrm{X}$ chromosome of female preimplantation mouse embryos. Development 127 2283-2289.

Csankovszki G, Nagy A \& Jaenisch R 2001 Synergism of Xist RNA, DNA methylation, and histone hypoacetylation in maintaining $X$ chromosome inactivation. Journal of Cell Biology 153 773-784. (doi:10.1083/jcb.153. 4.773)

Davis P \& Brachmann R 2003 Chromatin remodeling and cancer. Cancer Biology \& Therapy 2 24-31.

Deakin J, Chaumeil J, Hore T \& Marshall Graves J 2009 Unravelling the evolutionary origins of $\mathrm{X}$ chromosome inactivation in mammals: insights from marsupials and monotremes. Chromosome Research 17 671-685. (doi:10.1007/s10577-009-9058-6)

De La Fuente R, Viveiros M, Wigglesworth K \& Eppig J 2004 ATRX, a member of the SNF2 family of helicase/ATPases, is required for chromosome alignment and meiotic spindle organization in metaphase II stage mouse oocytes. Developmental Biology 272 1-14. (doi:10.1016/ j.ydbio.2003.12.012)

Dhayalan A, Tamas R, Bock I, Tattermusch A, Dimitrova E, Kudithipudi S, Ragozin S \& Jeltsch A 2011 The ATRX-ADD domain binds to H3 tail peptides and reads the combined methylation state of K4 and K9. Human Molecular Genetics 20 2195-2203. (doi:10.1093/hmg/ddr107)

Drane P, Ouararhni K, Depaux A, Shuaib M \& Hamiche A 2010 The deathassociated protein DAXX is a novel histone chaperone involved in the replication-independent deposition of H3.3. Genes and Development 24 1253-1265. (doi:10.1101/gad.566910)

Elsasser SJ, Allis CD \& Lewis PW 2011 New epigenetic drivers of cancers. Science 331 1145-1146. (doi:10.1126/science.1203280)

Eskeland R, Leeb M, Grimes GR, Kress C, Boyle S, Sproul D, Gilbert N, Fan Y, Skoultchi AI, Wutz A et al. 2010 Ring1B compacts chromatin structure and represses gene expression independent of histone ubiquitination. Molecular Cell 38 452-464. (doi:10.1016/j.molcel.2010.02.032)

Fang J, Chen T, Chadwick B, Li E \& Zhang Y 2004 Ring1b-mediated H2A ubiquitination associates with inactive $\mathrm{X}$ chromosomes and is involved in initiation of $X$ inactivation. Journal of Biological Chemistry 279 52812-52815. (doi:10.1074/jbc.C400493200)

Feinberg AP, Ohlsson R \& Henikoff S 2006 The epigenetic progenitor origin of human cancer. Nature Reviews. Genetics 7 21-33. (doi:10.1038/ nrg1748)

Ganesan S, Silver DP, Greenberg RA, Avni D, Drapkin R, Miron A, Mok SC, Randrianarison V, Brodie S, Salstrom J et al. 2002 BRCA1 supports XIST RNA concentration on the inactive $X$ chromosome. Cell 111 393-405. (doi:10.1016/S0092-8674(02)01052-8)

Garrick D, Samara V, McDowell TL, Smith AJ, Dobbie L, Higgs DR \& Gibbons RJ 2004 A conserved truncated isoform of the ATR-X syndrome protein lacking the SWI/SNF-homology domain. Gene 326 23-34. (doi:10.1016/j.gene.2003.10.026)
Garrick D, Sharpe JA, Arkell R, Dobbie L, Smith AJ, Wood WG, Higgs DR \& Gibbons RJ 2006 Loss of Atrx affects trophoblast development and the pattern of X-inactivation in extraembryonic tissues. PLoS Genetics 2 e58. (doi:10.1371/journal.pgen.0020058)

Gibbons RJ \& Higgs DR 2000 Molecular-clinical spectrum of the ATR-X syndrome. American Journal of Medical Genetics 97 204-212. (doi:10. 1002/1096-8628(200023)97:3 <204::AID-AJMG1038> 3.0.CO;2-X)

Gibbons RJ, Picketts DJ, Villard L \& Higgs DR 1995 Mutations in a putative global transcriptional regulator cause X-linked mental retardation with alpha-thalassemia (ATR-X syndrome). Cell 80 837-845. (doi:10.1016/ 0092-8674(95)90287-2)

Gibbons R, Bachoo S, Picketts D, Aftimos S, Asenbauer B, Bergoffen J, Berry S, Dahl N, Fryer A, Keppler K et al. 1997 Mutations in transcriptional regulator ATRX establish the functional significance of a PHD-like domain. Nature Genetics 17 146-148. (doi:10.1038/ ng1097-146)

Gibbons RJ, McDowell TL, Raman S, O'Rourke DM, Garrick D, Ayyub H \& Higgs DR 2000 Mutations in ATRX, encoding a SWI/SNF-like protein, cause diverse changes in the pattern of DNA methylation. Nature Genetics 24 368-371. (doi:10.1038/74191)

Gibbons RJ, Pellagatti A, Garrick D, Wood WG, Malik N, Ayyub H, Langford C, Boultwood J, Wainscoat JS \& Higgs DR 2003 Identification of acquired somatic mutations in the gene encoding chromatinremodeling factor ATRX in the [alpha]-thalassemia myelodysplasia syndrome (ATMDS). Nature Genetics 34 446-449. (doi:10.1038/ ng1213)

Gibbons R, Wada T, Fisher C, Malik N, Mitson M, Steensma D, Fryer A, Goudie D, Krantz I \& Traeger-Synodinos J 2008 Mutations in the chromatin-associated protein ATRX. Human Mutation 29 796-802. (doi:10.1002/humu.20734)

Goldberg AD, Banaszynski LA, Noh K-M, Lewis PW, Elsaesser SJ, Stadler S, Dewell S, Law M, Guo X, Li X et al. 2010 Distinct factors control histone variant H3.3 localization at specific genomic regions. Cell 140 678-691. (doi:10.1016/j.cell.2010.01.003)

Gregg C, Zhang J, Butler JE, Haig D \& Dulac C 2010a Sex-specific parentof-origin allelic expression in the mouse brain. Science 329 682-685. (doi:10.1126/science.1190831)

Gregg C, Zhang J, Weissbourd B, Luo S, Schroth GP, Haig D \& Dulac C $2010 \mathrm{~b}$ High-resolution analysis of parent-of-origin allelic expression in the mouse brain. Science 329 643-648. (doi:10.1126/science.1190830)

Haas P, Roy NBA, Gibbons R, Deville M, Fisher C, Schwabe M, Bissé E, Dorsselaer A, Higgs D \& Lubbert M 2009 The role of X-inactivation in the gender bias of patients with acquired alpha-thalassaemia and myelodysplastic syndrome (ATMDS). British Journal of Haematology 144 538-545. (doi:10.1111/j.1365-2141.2008.07505.x)

Hall LL, Byron M, Sakai K, Carrel L, Willard HF \& Lawrence JB 2002 An ectopic human XIST gene can induce chromosome inactivation in postdifferentiation human HT-1080 cells. PNAS 99 8677-8682. (doi:10. 1073/pnas.132468999)

Hall LL, Byron M, Butler J, Becker KA, Nelson A, Amit M, Itskovitz-Eldor J, Stein J, Stein G, Ware C et al. 2008 X-inactivation reveals epigenetic anomalies in most hESC but identifies sublines that initiate as expected. Journal of Cellular Physiology 216 445-452. (doi:10.1002/jcp.21411)

Hall LL, Byron M, Pageau G \& Lawrence JB 2009 AURKB-mediated effects on chromatin regulate binding versus release of XIST RNA to the inactive chromosome. Journal of Cell Biology 186 491-507. (doi:10.1083/jcb. 200811143)

Heard E \& Disteche CM 2006 Dosage compensation in mammals: finetuning the expression of the X chromosome. Genes and Development 20 1848-1867. (doi:10.1101/gad.1422906)

Heard E, Rougeulle C, Arnaud D, Avner P, Allis CD \& Spector DL 2001 Methylation of histone $\mathrm{H} 3$ at Lys-9 is an early mark on the $\mathrm{X}$ chromosome during $X$ inactivation. Cell 107 727-738. (doi:10.1016/S00928674(01)00598-0)

Helbig R \& Fackelmayer FO 2003 Scaffold attachment factor A (SAF-A) is concentrated in inactive $X$ chromosome territories through its RGG domain. Chromosoma 112 173-182. (doi:10.1007/s00412-003-0258-0)

Hellman A \& Chess A 2007 Gene body-specific methylation on the active X chromosome. Science 315 1141-1143. (doi:10.1126/science.1136352)

Hendrich BD, Brown CJ \& Willard HF 1993 Evolutionary conservation of possible functional domains of the human and murine XIST genes. Human Molecular Genetics 2 663-672. (doi:10.1093/hmg/2.6.663) 
Hernandez-Munoz I, Lund AH, van der Stoop P, Boutsma E, Muijrers I, Verhoeven E, Nusinow DA, Panning B, Marahrens Y \& van Lohuizen M 2005 Stable $\mathrm{X}$ chromosome inactivation involves the PRC1 polycomb complex and requires histone MACROH2A1 and the CULLIN3/SPOP ubiquitin E3 ligase. PNAS 102 7635-7640. (doi:10.1073/pnas.04089 18102)

Ishov AM, Vladimirova OV \& Maul GG 2004 Heterochromatin and ND10 are cell-cycle regulated and phosphorylation-dependent alternate nuclear sites of the transcription repressor Daxx and SWI/SNF protein ATRX. Journal of Cell Science 117 3807-3820. (doi:10.1242/jcs.01230)

Jeppesen P \& Turner BM 1993 The inactive X chromosome in female mammals is distinguished by a lack of histone $\mathrm{H} 4$ acetylation, a cytogenetic marker for gene expression. Cell 74 281-289. (doi:10.1016/ 0092-8674(93)90419-Q)

Jiao Y, Shi C, Edil BH, de Wilde RF, Klimstra DS, Maitra A, Schulick RD, Tang LH, Wolfgang CL, Choti MA et al. 2011 DAXX/ATRX, MEN1, and mTOR pathway genes are frequently altered in pancreatic neuroendocrine tumors. Science 331 1199-1203. (doi:10.1126/science.1200609)

Jonkers I, Barakat TS, Achame EM, Monkhorst K, Kenter A, Rentmeester E, Grosveld F, Grootegoed JA \& Gribnau J 2009 RNF12 is an X-encoded dose-dependent activator of $X$ chromosome inactivation. Cell 139 999-1011. (doi:10.1016/j.cell.2009.10.034)

Kanduri C, Whitehead J \& Mohammad F 2009 The long and the short of it: RNA-directed chromatin asymmetry in mammalian X-chromosome inactivation. FEBS Letters 583 857-864. (doi:10.1016/j.febslet.2009. 02.004)

Kawakami T, Zhang C, Taniguchi T, Kim CJ, Okada Y, Sugihara H, Hattori T, Reeve AE, Ogawa O \& Okamoto K 2004 Characterization of lossof-inactive $\mathrm{X}$ in Klinefelter syndrome and female-derived cancer cells. Oncogene 23 6163-6169. (doi:10.1038/sj.onc.1207808)

Kernohan KD, Jiang Y, Tremblay DC, Bonvissuto AC, Eubanks JH, Mann MRW \& Berube NG 2010 ATRX partners with cohesin and MeCP2 and contributes to developmental silencing of imprinted genes in the brain. Developmental Cell 18 191-202. (doi:10.1016/j.devcel.2009. 12.017)

Kim M, Mauro S, Gevry N, Lis J \& Kraus W 2004 NAD(+)-dependent modulation of chromatin structure and transcription by nucleosome binding properties of PARP-1. Cell 119 803-814. (doi:10.1016/j.cell. 2004.11.002)

Kim MY, Zhang T \& Kraus WL 2005 Poly(ADP-ribosyl)ation by PARP-1: 'PAR-laying' $\mathrm{NAD}^{+}$into a nuclear signal. Genes and Development 19 1951-1967. (doi:10.1101/gad.1331805)

Law MJ, Lower KM, Voon HPJ, Hughes JR, Garrick D, Viprakasit V, Mitson M, De Gobbi M, Marra M, Morris A et al. 2010 ATR-X syndrome protein targets tandem repeats and influences allele-specific expression in a size-dependent manner. Cell 143 367-378. (doi:10.1016/j.cell. 2010.09.023)

Lee JT 2009 Lessons from X-chromosome inactivation: long ncRNA as guides and tethers to the epigenome. Genes and Development 23 1831-1842. (doi:10.1101/gad.1811209)

Lee JT \& Jaenisch R 1997 The (epi)genetic control of mammalian $\mathrm{X}$-chromosome inactivation. Current Opinion in Genetics \& Development 7 274-280. (doi:10.1016/S0959-437X(97)80138-4)

Lee JT \& Lu N 1999 Targeted mutagenesis of Tsix leads to nonrandom X inactivation. Cell 99 47-57. (doi:10.1016/S0092-8674(00)80061-6)

Lee JT, Davidow LS \& Warshawsky D 1999 Tsix, a gene antisense to Xist at the X-inactivation centre. Nature Genetics 21 400-404. (doi:10.1038/7734)

Lengner CJ, Gimelbrant AA, Erwin JA, Cheng AW, Guenther MG, Welstead GG, Alagappan R, Frampton GM, Xu P, Muffat J et al. 2010 Derivation of pre-X inactivation human embryonic stem cells under physiological oxygen concentrations. Cell 141 872-883. (doi:10.1016/j. cell.2010.04.010)

Lewis PW, Elsaesser SJ, Noh K-M, Stadler SC \& Allis CD 2010 Daxx is an $\mathrm{H} 3.3$-specific histone chaperone and cooperates with ATRX in replication-independent chromatin assembly at telomeres. PNAS $\mathbf{1 0 7}$ 14075-14080. (doi:10.1073/pnas.1008850107)

Lyon MF 1961 Gene action in the X-chromosome of the mouse. Nature 190 372-373. (doi:10.1038/190372a0)

Mahadevaiah SK, Royo H, VandeBerg JL, McCarrey JR, Mackay S \& Turner JMA 2009 Key features of the $X$ inactivation process are conserved between marsupials and eutherians. Current Biology 19 1478-1484. (doi:10.1016/j.cub.2009.07.041)
Mak W, Baxter J, Silva J, Newall AE, Otte AP \& Brockdorff N 2002 Mitotically stable association of polycomb group proteins eed and enx 1 with the inactive $\mathrm{x}$ chromosome in trophoblast stem cells. Current Biology 12 1016-1020. (doi:10.1016/S0960-9822(02)00892-8)

Marahrens Y, Panning B, Dausman J, Strauss W \& Jaenisch R 1997 Xist-deficient mice are defective in dosage compensation but not spermatogenesis. Genes and Development 11 156-166. (doi:10.1101/ gad.11.2.156)

Marks H, Chow JC, Denissov S, Francoijs K-J, Brockdorff N, Heard E \& Stunnenberg HG 2009 High-resolution analysis of epigenetic changes associated with X inactivation. Genome Research 19 1361-1373. (doi:10.1101/gr.092643.109)

McDowell TL, Gibbons RJ, Sutherland H, O'Rourke DM, Bickmore WA, Pombo A, Turley H, Gatter K, Picketts DJ \& Buckle VJ 1999 Localization of a putative transcriptional regulator (ATRX) at pericentromeric heterochromatin and the short arms of acrocentric chromosomes. PNAS 96 13983-13988. (doi:10.1073/pnas.96.24.13983)

Ménissier de Murcia J, Ricoul M, Tartier L, Niedergang C, Huber A, Dantzer F, Schreiber V, Amé J, Dierich A, LeMeur M et al. 2003 Functional interaction between PARP-1 and PARP-2 in chromosome stability and embryonic development in mouse. EMBO Journal 22 2255-2263. (doi:10.1093/emboj/cdg206)

Migeon BR 2006 The role of X inactivation and cellular mosaicism in women's health and sex-specific diseases. Journal of the American Medical Association 295 1428-1433. (doi:10.1001/jama.295.12.1428)

Migeon BR 2008 X inactivation, female mosaicism, and sex differences in renal diseases. Journal of the American Society of Nephrology 19 2052-2059. (doi:10.1681/ASN.2008020198)

Migeon BR, Luo S, Stasiowski BA, Jani M, Axelman J, Van Dyke DL, Weiss L, Jacobs PA, Yang-Feng TL \& Wiley JE 1993 Deficient transcription of XIST from tiny ring $X$ chromosomes in females with severe phenotypes. PNAS 90 12025-12029. (doi:10.1073/pnas.90.24. 12025)

Moens P, Kolas N, Tarsounas M, Marcon E, Cohen P \& Spyropoulos B 2002 The time course and chromosomal localization of recombination-related proteins at meiosis in the mouse are compatible with models that can resolve the early DNA-DNA interactions without reciprocal recombination. Journal of Cell Science 115 1611-1622.

Mohandas T, Sparkes R \& Shapiro L 1981 Reactivation of an inactive human $\mathrm{X}$ chromosome: evidence for $\mathrm{X}$ inactivation by DNA methylation. Science 211 393-396. (doi:10.1126/science.6164095)

Muers MR, Sharpe JA, Garrick D, Sloane-Stanley J, Nolan PM, Hacker T, Wood WG, Higgs DR \& Gibbons RJ 2007 Defining the cause of skewed $\mathrm{X}$-chromosome inactivation in X-linked mental retardation by use of a mouse model. American Journal of Human Genetics 80 1138-1149. (doi:10.1086/518369)

Nan X, Hou J, Maclean A, Nasir J, Lafuente MJ, Shu X, Kriaucionis S \& Bird A 2007 Interaction between chromatin proteins MECP2 and ATRX is disrupted by mutations that cause inherited mental retardation. PNAS 104 2709-2714. (doi:10.1073/pnas.0608056104)

de Napoles M, Mermoud JE, Wakao R, Tang YA, Endoh M, Appanah R, Nesterova TB, Silva J, Otte AP, Vidal M et al. 2004 Polycomb group proteins Ring1 $\mathrm{A} / \mathrm{B}$ link ubiquitylation of histone $\mathrm{H} 2 \mathrm{~A}$ to heritable gene silencing and X inactivation. Developmental Cell 7 663-676. (doi:10. 1016/j.devcel.2004.10.005)

Naughton C, Sproul D, Hamilton C \& Gilbert N 2010 Analysis of active and inactive $\mathrm{X}$ chromosome architecture reveals the independent organization of $30 \mathrm{~nm}$ and large-scale chromatin structures. Molecular Cell $\mathbf{4 0}$ 397-409. (doi:10.1016/j.molcel.2010.10.013)

Navarro P, Chambers I, Karwacki-Neisius V, Chureau C, Morey C, Rougeulle C \& Avner P 2008 Molecular coupling of Xist regulation and pluripotency. Science 321 1693-1695. (doi:10.1126/science.1160952)

Ng K, Pullirsch D, Leeb M \& Wutz A 2007 Xist and the order of silencing. EMBO Reports 8 34-39. (doi:10.1038/sj.embor.7400871)

Nguyen DK \& Disteche CM 2006 Dosage compensation of the active X chromosome in mammals. Nature Genetics 38 47-53. (doi:10.1038/ ng1705)

Nusinow DA, Hernandez-Munoz I, Fazzio TG, Shah GM, Kraus WL \& Panning B 2007 Poly(ADP-ribose) polymerase 1 is inhibited by a histone $\mathrm{H} 2 \mathrm{~A}$ variant, MacroH2A, and contributes to silencing of the inactive $\mathrm{X}$ chromosome. Journal of Biological Chemistry 282 12851-12859. (doi:10.1074/jbc.M610502200) 
Ogawa Y \& Lee JT 2003 Xite, X-inactivation intergenic transcription elements that regulate the probability of choice. Molecular Cell $\mathbf{1 1}$ 731-743. (doi:10.1016/S1097-2765(03)00063-7)

Okamoto I \& Heard E 2009 Lessons from comparative analysis of $\mathrm{X}$-chromosome inactivation in mammals. Chromosome Research 17 659-669. (doi:10.1007/s10577-009-9057-7)

Okamoto I, Patrat C, Thepot D, Peynot N, Fauque P, Daniel N, Diabangouaya P, Wolf J, Renard J, Duranthon V et al. 2011 Eutherian mammals use diverse strategies to initiate $\mathrm{X}$-chromosome inactivation during development. Nature 472 370-374. (doi:10.1038/nature09872)

O'Neill LP, Keohane AM, Lavender JS, McCabe V, Heard E, Avner P, Brockdorff N \& Turner BM 1999 A developmental switch in H4 acetylation upstream of Xist plays a role in X chromosome inactivation. EMBO Journal 18 2897-2907. (doi:10.1093/emboj/18.10.2897)

Ouararhni K, Hadj-Slimane R, Ait-Si-Ali S, Robin P, Mietton F, HarelBellan A, Dimitrov S \& Hamiche A 2006 The histone variant mH2A1.1 interferes with transcription by down-regulating PARP-1 enzymatic activity. Genes and Development 20 3324-3336. (doi:10.1101/gad. 396106)

Pageau GJ, Hall LL, Ganesan S, Livingston DM \& Lawrence JB 2007 The disappearing Barr body in breast and ovarian cancers. Nature Reviews. Cancer 7 628-633. (doi:10.1038/nrc2172)

Pan Y \& Sawalha AH 2009 Epigenetic regulation and the pathogenesis of systemic lupus erythematosus. Translational Research 153 4-10. (doi:10. 1016/j.trsl.2008.10.007)

Pandey RR, Mondal T, Mohammad F, Enroth S, Redrup L, Komorowski J, Nagano T, Mancini-Dinardo D \& Kanduri C 2008 Kcnq1ot1 antisense noncoding RNA mediates lineage-specific transcriptional silencing through chromatin-level regulation. Molecular Cell 32 232-246. (doi:10.1016/j.molcel.2008.08.022)

Patrat C, Okamoto I, Diabangouaya P, Vialon V, Le Baccon P, Chow J \& Heard E 2009 Dynamic changes in paternal X-chromosome activity during imprinted $\mathrm{X}$-chromosome inactivation in mice. PNAS 106 5198-5203. (doi:10.1073/pnas.0810683106)

Payer B \& Lee JT 2008 X chromosome dosage compensation: how mammals keep the balance. Annual Review of Genetics 42 733-772. (doi:10.1146/annurev.genet.42.110807.091711)

Picketts DJ, Higgs DR, Bachoo S, Blake DJ, Quarrell OW \& Gibbons RJ 1996 ATRX encodes a novel member of the SNF2 family of proteins: mutations point to a common mechanism underlying the ATR-X syndrome. Human Molecular Genetics 5 1899-1907. (doi:10.1093/ hmg/5.12.1899)

Picketts DJ, Tastan AO, Higgs DR \& Gibbons RJ 1998 Comparison of the human and murine ATRX gene identifies highly conserved, functionally important domains. Mammalian Genome 9 400-403. (doi:10.1007/ s003359900781)

Plath K, Fang J, Mlynarczyk-Evans SK, Cao R, Worringer KA, Wang H, de la Cruz CC, Otte AP, Panning B \& Zhang Y 2003 Role of histone H3 lysine 27 methylation in $X$ inactivation. Science 300 131-135. (doi:10.1126/ science.1084274)

Plath K, Talbot D, Hamer KM, Otte AP, Yang TP, Jaenisch R \& Panning B 2004 Developmentally regulated alterations in polycomb repressive complex 1 proteins on the inactive $\mathrm{X}$ chromosome. Journal of Cell Biology 167 1025-1035. (doi:10.1083/jcb.200409026)

Pullirsch D, Haertel R, Kishimoto H, Leeb M, Steiner G \& Wutz A 2010 The Trithorax group protein Ash2l and Saf-A are recruited to the inactive $X$ chromosome at the onset of stable $X$ inactivation. Development 137 935-943. (doi:10.1242/dev.035956)

Raymond FL 2006 X linked mental retardation: a clinical guide. Journal of Medical Genetics 43 193-200. (doi:10.1136/jmg.2005.033043)

Rens W, Wallduck MS, Lovell FL, Ferguson-Smith MA \& Ferguson-Smith AC 2010 Epigenetic modifications on $X$ chromosomes in marsupial and monotreme mammals and implications for evolution of dosage compensation. PNAS 107 17657-17662. (doi:10.1073/pnas.0910322107)

Ritchie K, Seah C, Moulin J, Issac C, Dick F \& Berube NG 2008 Loss of ATRX leads to chromosome cohesion and congression defects. Journal of Cell Biology 180 315-324. (doi:10.1083/jcb.200706083)

Rougeulle C, Chaumeil J, Sarma K, Allis CD, Reinberg D, Avner P \& Heard E 2004 Differential histone H3 Lys-9 and Lys-27 methylation profiles on the $X$ chromosome. Molecular and Cellular Biology 24 5475-5484. (doi:10.1128/MCB.24.12.5475-5484.2004)
Serrano E, Lasa A, Perea G, Carnicer M, Brunet S, Aventín A, Sierra J \& Nomdedéu J 2006 Acute myeloid leukemia subgroups identified by pathway-restricted gene expression signatures. Acta Haematologica 116 77-89. (doi:10.1159/000093636)

Shumaker DK, Dechat T, Kohlmaier A, Adam SA, Bozovsky MR, Erdos MR, Eriksson M, Goldman AE, Khuon S, Collins FS et al. 2006 Mutant nuclear lamin A leads to progressive alterations of epigenetic control in premature aging. PNAS 103 8703-8708. (doi:10.1073/pnas.0602569103)

Silva J, Mak W, Zvetkova I, Appanah R, Nesterova TB, Webster Z, Peters AH, Jenuwein T, Otte AP \& Brockdorff N 2003 Establishment of histone $\mathrm{h} 3$ methylation on the inactive $\mathrm{X}$ chromosome requires transient recruitment of Eed-Enx1 polycomb group complexes. Developmental Cell 4 481-495. (doi:10.1016/S1534-5807(03)00068-6)

Silva SS, Rowntree RK, Mekhoubad S \& Lee JT 2008 X-chromosome inactivation and epigenetic fluidity in human embryonic stem cells. PNAS 105 4820-4825. (doi:10.1073/pnas.0712136105)

Smith KP, Byron M, Clemson CM \& Lawrence JB 2004 Ubiquitinated proteins including $\mathrm{uH} 2 \mathrm{~A}$ on the human and mouse inactive $X$ chromosome: enrichment in gene rich bands. Chromosoma 113 324-335. (doi:10.1007/s00412-004-0325-1)

Sporn JC, Kustatscher G, Hothorn T, Collado M, Serrano M, Muley T, Schnabel P \& Ladurner AG 2009 Histone macroH2A isoforms predict the risk of lung cancer recurrence. Oncogene 28 3423-3428. (doi:10.1038/ onc.2009.26)

Stavropoulos N, Rowntree RK \& Lee JT 2005 Identification of developmentally specific enhancers for Tsix in the regulation of $X$ chromosome inactivation. Molecular and Cellular Biology 25 2757-2769. (doi:10. 1128/MCB.25.7.2757-2769.2005)

Steensma DP, Higgs DR, Fisher CA \& Gibbons RJ 2004 Acquired somatic ATRX mutations in myelodysplastic syndrome associated with \{alpha\} thalassemia (ATMDS) convey a more severe hematologic phenotype than germline ATRX mutations. Blood 103 2019-2026. (doi:10.1182/blood2003-09-3360)

Steensma DP, Gibbons RJ \& Higgs DR 2005 Acquired alpha-thalassemia in association with myelodysplastic syndrome and other hematologic malignancies. Blood 105 443-452. (doi:10.1182/blood-2004-07-2792)

Steensma DP, Porcher JC, Litzow MR, Hogan WJ, Arora S \& Van Laar ES 2009 Assessment of ATRX expression in patients with myelodysplastic syndromes treated with decitabine. Leukemia Research 33 e81-e82. (doi:10.1016/j.leukres.2008.11.030)

Sun BK \& Tsao H 2008 X-chromosome inactivation and skin disease. Journal of Investigative Dermatology 128 2753-2759. (doi:10.1038/jid. 2008.145)

Takagi N \& Abe K 1990 Detrimental effects of two active X chromosomes on early mouse development. Development 109 189-201.

Tang J, Wu S, Liu H, Stratt R, Barak OG, Shiekhattar R, Picketts DJ \& Yang X 2004a A novel transcription regulatory complex containing death domain-associated protein and the ATR-X syndrome protein. Journal of Biological Chemistry 279 20369-20377. (doi:10.1074/jbc.M401321200)

Tang P, Park DJ, Marshall Graves JA \& Harley VR 2004b ATRX and sex differentiation. Trends in Endocrinology and Metabolism 15 339-344. (doi:10.1016/j.tem.2004.07.006)

Tang P, Argentaro A, Pask AJ, O'Donnell L, Marshall-Graves J, Familari M \& Harley VR 2011 Localisation of the chromatin remodelling protein, ATRX in the adult testis. Journal of Reproduction and Development [in press]. (doi:10.1262/jrd.20221)

Timinszky G, Till S, Hassa PO, Hothorn M, Kustatscher G, Nijmeijer B, Colombelli J, Altmeyer M, Stelzer EHK, Scheffzek K et al. 2009 A macrodomain-containing histone rearranges chromatin upon sensing PARP1 activation. Nature Structural \& Molecular Biology 16 923-929. (doi:10.1038/nsmb.1664)

Trojer P \& Reinberg D 2007 Facultative heterochromatin: is there a distinctive molecular signature? Molecular Cell 28 1-13. (doi:10.1016/j. molcel.2007.09.011)

Tulin A \& Spradling A 2003 Chromatin loosening by poly(ADP)-ribose polymerase (PARP) at Drosophila puff loci. Science 299 560-562. (doi:10.1126/science.1078764)

Tulin A, Stewart D \& Spradling AC 2002 The Drosophila heterochromatic gene encoding poly (ADP-ribose) polymerase (PARP) is required to modulate chromatin structure during development. Genes and Development 16 2108-2119. (doi:10.1101/gad.1003902) 
Vialard F, Petit C, Bergere M, Gomes DM, Martel-Petit V, Lombroso R, Ville Y, Gerard H \& Selva J 2006 Evidence of a high proportion of premature unbalanced separation of sister chromatids in the first polar bodies of women of advanced age. Human Reproduction 21 1172-1178. (doi:10.1093/humrep/dei484)

Villard L, Lossi AM, Cardoso C, Proud V, Chiaroni P, Colleaux L, Schwartz C \& Fontés M 1997 Determination of the genomic structure of the XNP/ATRX gene encoding a potential zinc finger helicase. Genomics 43 149-155. (doi:10.1006/geno.1997.4793)

Vincent-Salomon A, Ganem-Elbaz C, Manié E, Raynal V, Sastre-Garau X, Stoppa-Lyonnet D, Stern M-H \& Heard E 2007 X inactive-specific transcript RNA coating and genetic instability of the $X$ chromosome in BRCA1 breast tumors. Cancer Research 67 5134-5140. (doi:10.1158/ 0008-5472.CAN-07-0465)

Wang J, Mager J, Chen Y, Schneider E, Cross JC, Nagy A \& Magnuson T 2001 Imprinted $X$ inactivation maintained by a mouse Polycomb group gene. Nature Genetics 28 371-375. (doi:10.1038/ng574)

Wong L, McGhie J, Sim M, Anderson M, Ahn S, Hannan R, George A, Morgan KA, Mann J \& Choo KH 2010 ATRX interacts with $\mathrm{H} 3.3$ in maintaining telomere structural integrity in pluripotent embryonic stem cells. Genome Research 20 351-360. (doi:10.1101/ gr.101477.109)
Xu N, Tsai C-L \& Lee JT 2006 Transient homologous chromosome pairing marks the onset of X inactivation. Science 311 1149-1152. (doi:10.1126/ science.1122984)

Xue Y, Gibbons R, Yan Z, Yang D, McDowell TL, Sechi S, Qin J, Zhou S, Higgs D \& Wang W 2003 The ATRX syndrome protein forms a chromatin-remodeling complex with Daxx and localizes in promyelocytic leukemia nuclear bodies. PNAS 100 10635-10640. (doi:10.1073/ pnas.1937626100)

Yang F, Baumann C \& De La Fuente R 2009 Persistence of histone H2AX phosphorylation after meiotic chromosome synapsis and abnormal centromere cohesion in poly (ADP-ribose) polymerase (Parp-1) null oocytes. Developmental Biology 331 326-338. (doi:10.1016/j.ydbio.2009.05.550)

Zhang LF, Huynh KD \& Lee JT 2007 Perinucleolar targeting of the inactive X during $S$ phase: evidence for a role in the maintenance of silencing. Cell 129 693-706. (doi:10.1016/j.cell.2007.03.036)

Received 7 September 2010

First decision 25 October 2010

Revised manuscript received 10 May 2011

Accepted 8 June 2011 